\title{
Kamu Alacaklarının Korunmasında Hükümsüz Sayılan Tasarruflar ve Tasarrufun İptali Davası ${ }^{1}$
}

\section{Non-Legal Savings in Protection of Public Receivables and Cancellation of Savings}

\author{
Semra ALTINGÖZ ZARPLI ${ }^{2 *} \&$ Abdullah DURAN ${ }^{3}$
}

Geliş / Received: 06/10/2021

Kabul / Accepted: 12/10/2021

\begin{abstract}
$\ddot{\text { ÖZ }}$
Kamu alacaklarının tahsilinde egemenlik gücünü kullanan devlet, kamu alacaklarının hızlı ve etkin bir şekilde tahsili için birtakım önlemler almaktadır. Bu önlemlerden birisi de 6183 Sayılı AATUHK kanunda da açıklandığ 1 gibi bazı tasarrufların hükümsüz sayılmasını içermektedir. Kamu alacağının koruma yöntemlerinden biri olan bu yöntem, kamu alacağının tahsilinde cebren uygulanabileceği gibi yine alacağın tahsilinde bu alacağı müşkül kılabilecek özelliği bulunan bazı tasarruf edinişlerini de göz önüne alarak geçersiz sayabilmektedir. Kamu alacakları tahsil edilirken bir koruma metodu olarak kullanılan bu yöntem, diğer koruma yöntemlerinde olduğu gibi ortak amaca hizmet etmekte; borçluların alacaklılardan mal kaçırmasını engellemek ve kötü niyetli olarak yapmış oldukları hukuki işlemlerin hükümsüz sayılarak, alacağın temin edilmesini sağlamaktır. Bu konunun incelemesindeki amaç tasarrufun iptali davasına konu olan tasarrufların neler olduğu incelenmiş olup davanın açılabilmesi için koşulların neler olduğu, muhatabı, hangi yasal süreler içerisinde açılabileceği, bunun sonucunun nelere sebebiyet vereceği, 1998 yılından günümüze tasarrufun iptali davasının yıllar itibariyle seyri incelenmiş ve mevzuatta görülen birtakım eksikliklere çözüm önerileri sunulmuş bulunmaktadır.
\end{abstract}

Anahtar Kelimeler- Kamu Alacakları, Tasarrufun İptal Davası, Rüçhan Hakkı, Kamu Alacaklarının Tahsili

\begin{abstract}
The state, which uses sovereign power in the collection of public receivables, takes some measures for the rapid and effective collection of public receivables. One of these measures includes the deprivation of certain savings as explained in the Law No. 6183 of the AATUHK. This method, which is one of the protection methods of the public receivable, may be applied by force in the collection of the public receivable, and may also be deemed invalid by taking into account some of the savings acquisitions that may make this receivable in the collection of the receivable. This method, which is used as a protection method when collecting public receivables, serves the same purpose as other protection methods; to prevent the borrowers from smuggling goods, and to ensure that the receivables are deemed null and void. The purpose of the examination of this subject is to examine the dispositions that are the subject of the action for the annulment of the disposition, what the conditions are for the lawsuit to be filed, the addressee, within which legal period it can be filed, what the result of this will cause, the course of the action for the annulment of the disposition from 1998 to the present has been examined, and some issues seen in the legislation have been examined. Solutions to the shortcomings have been proposed.
\end{abstract}

Keywords- Public Receivables, Lawsuit for Cancellation of Savings, Right of Rüchan, Collection of Public Receivables

\footnotetext{
${ }^{1}$ Bu makale, Bilecik Şeyh Edebali Üniversitesi, Sosyal Bilimler Enstitüsü, Maliye Anabilim Dalında, Dr. Öğr. Üyesi Semra ALTINGÖZ ZARPLI danışmanlığında 2019 yılında yürütülen "Kamu Alacaklarının Korunmasında Hükümsüz Sayılan Tasarruflar ve Tasarrufun İptali Davası" başlıklı yüksek lisans tezinden üretilmiştir.

2* Sorumlu Yazar, Dr. Öğr. Üyesi, Bilecik Şeyh Edebali Üniversitesi, İktisadi ve İdari Bilimler Fakültesi, Maliye Bölümü, semra.altingoz@bilecik.edu.tr, (https://orcid.org/0000-0003-4597-0193)

${ }^{3}$ Yüksek Lisans Öğrencisi, Gelir Uzman Yardımcısı, İstanbul Vergi Dairesi Başkanlığı, abdulah4211@gmail.com, (https://orcid.org/00000002-0583-8879)
} 


\section{GİRIŞ̧}

Devletin, egemenlik gücünü kullanarak elde edeceği kamu alacaklarının öneminin artan ihtiyaçlara göre daha da artması, bu alacakların önemini arttırdığı gibi, özel hukuk kurallarına nazaran daha ağır yaptırımlarla da donatılmasına neden olmuştur. Devlet alacaklarının korunmasına yönelik tedbirler çoğunlukla Tahsili Emval Kanunu'nu örnek alarak hazırlanmıştır. Bu nedenle 6183 Sayılı Kanun da devletin egemenliğini ve üstünlüğünü sert tedbirlerle yansitan bir mekanizmaya sahiptir.

Kamu harcamalarının finansmanı için yaşamsal öneme sahip olan kamu alacaklarının öneminin gün geçtikçe daha da arttığını görmekteyiz. Kamu alacaklarının tahsilinde egemenlik gücünü kullanan devlet, kamu alacaklarının hızlı ve etkin bir şekilde tahsili için birtakım önlemler almaktadır. Bu önlemlerden birisi de, kanunda da açıklandığı gibi bazı tasarrufların hükümsüz sayılmasını içermektedir. Kamu alacağının korunma yöntemlerinden biri olan bu yöntem, kamu alacağının tahsilinde cebri içerebileceği gibi, yine alacağın tahsilinde bu alacağı müşkül kılabilecek özelliği bulunan bazı tasarruf edinişlerini de göz önüne alarak geçersiz sayabilmektedir. Bu açıdan bakıldığında devletin kamu alacaklarının tahsilinde titiz davranış sergilediği göze çarpmaktadır.

\section{TASARRUFUN İPTALİ DAVASI}

Tasarrufun iptali davasının amacı, borçlu tarafından kamu alacağının tahsiline imkân vermemek için yapmış olduğu birtakım işlemlerin iptal edilmesini sağlayarak, dava konusu malın cebri takip yöntemlerinin uygulanması suretiyle kamu alacağının tahsilini mümkün kılmaktır.

\section{TASARRUFUN İPTAL DAVASININ HUKUKİ NITTELİĞİ}

Kesinleşen kamu alacaklarının tahsili sonraki aşamalarda çeşitli nedenlerle, tahsile olanak tanımayan tasarruf işlemleri ile zora sokulmaktadır. Hal böyle olunca, yasa yapıcı amme alacaklısına bazı haklar tanımıştır. Bunlardan bazıları; üzerine düşen borçlarını ödemeyen, hacze kabil malları olmayan veya malvarlığı borcuna oranla yetersiz kalan borçlulara karşı tasarrufun iptali davası açma hakkı tanımaktadır. Hukuk dilinde tasarrufun iptali davası olarak bilinen bu davalar, 6183 Sayılı Kanun' un 24. ve 31. maddeleri arasinda yer bulan bir dava türü olarak karşımıza çıkmaktadır (AATUHK md. 24-31).

6183 sayılı Kanun'da adı geçen iptal davası taşıdığı şekil şartları itibari ile tasarrufa dair bazı işlemlerin kamu alacağına zarar vermek amacı ile yapıldığının anlaşılması üzerine hükümsüz sayılmasını içeren bir dava türü olarak karşımıza çıkmaktadır (AATUHK md. 24-31).

6183 Sayılı Kanun’un da adı geçen iptal davasına ilişkin özellikleri içinde barındıran muamelelere girişen amme borçlularının, birtakım işlemleri geçersiz saydırılmaktadır. Bunlardan bazıları; çeşitli borç altına girme veya çeşitli devir işlemlerini kapsamaktadır. Buna göre; zamanaşımı da göz önünde bulundurarak, amme borçlusunun yaptığı karşılıksız tasarruflar, bağışlar, belli derecedeki yakına yapılan alacak devri işlemleri kamu alacağının tahsilini mümkün kılmamak için yapılan işlemlerdendir ve iptal ettirilip hükümsüz olduğuna karar verilebilir. Burada amaç yine kamu alacağının tahsilini etkin bir şekilde sağlanmaktır. Böylece amme alacaklısı, iptal davasına konu teşkil eden değerler üzerinden alacağını tahsil etme olanağına kavuşur. (Öncel, Çağan ve Kumrulu,1985: 197).

\section{TASARRUFUN İPTALİ DAVASININ KONUSU}

Tasarrufun iptaline konu olan davalar esas itibari ile borçlunun alacaklısından mal kaçırmaya yönelik yaptığı tasarruflara karşı açılan bir dava türüdür. 6183 sayılı kanun ile kamu alacağı güvence altına alınmaya çalışılmış, şüpheli durum veya kötü niyete olanak sağlayan hallerde uygulanacak bazı düzenlemelere gidilmiştir. $\mathrm{Bu}$ düzenlemelerden biri de iptal davasına konu olan hükümsüz tasarruflardır. Kanunun 24. maddesinde bu amaçla yapılan düzenleme ile iptale konu olan tasarruflar üç grupta toplanmıştır (Özhan, 2010: 101).

•İvazsız tasarruflarla hibe olarak sayılan tasarruflar (AATUHK md. 27-28)

-Batıl olarak ele alınan diğer tasarruflar (AATUHK md. 29)

-Sonuncu ise, amme alacağının tahsiline imkân tanımamak amacıyla yapılan tasarrufları içermektedir. (AATUHK md. 30). Bu maddeler geçen muameleler, bir tasarruf transferi işlemleridir ve yine düzenlenen bu işlemler, borçlu tarafın normal bir zamanda her şey yolunda iken yapacağı tasarruf işlemleri değildir. 


\section{TASARRUFUN IPTALII DAVASINDA MUHATAP}

Alacaklı tarafta bulunan kamu idaresi yahut alacağın tahsili ile görevlendirilmiş bir başka idare tarafından açılan iptal davası 6183 Sayılı Kanun'un 25'inci maddesi ile kimlere karşı açılacağı açıkça belirtilmiştir. Bunlar aşağıdaki gibidir:

-Borçlu taraf ile hukuki alışverişte bulunan kimselere,

-Borçlunun tarafindan herhangi bir şekilde yapılan tediyeler,

-Bunların mirasçılarına,

•Suiniyet taşıyan diğer üçüncü kişilere karşı açılır.

Kanunda belirtilen bu dört durumda, taraflarca geçerli olan zorunlu dava arkadaşlı̆̆ bulunmaktadır ve yine alacaklı, kanunun tanımış olduğu sınırlar içerisinde iptal davasını bu kişilere yöneltmek mecburiyetindedir. Hal böyle olunca iptal davası, lehte tasarruf işleminde bulunanlar veya bunların mirasçıları sıfatını taşıyanlara karşı açılması gereken bir dava türü olarak karşımıza çıkmaktadır. Çünkü bu tür davalar yapıları itibari ile borçluyu hatta üçüncü dördüncü kişileri bile etkilemektedir. Fakat tüm bunlardan önce hükümsüz sayılacak tasarruf işlemi hakkında, borçlunun göstereceği kanıtlar doğrultusunda ilerlenmeli ve yapacağı savunmasının dikkate alınması gerekmektedir (Özhan, 2010: 107).

\section{TASARRUFUN İPTALİ DAVASINDA SÜRE}

Borçluların girişmiş oldukları batıl tasarruf işlemlerinde yasa koyucu, bu işlemlerin geçersiz sayılması amacı ile açılacak iptal davalarını belirli bir süre ile sınırlamıştır. Kanunda atıf yapılan maddelere istinaden, tasarrufların vukuu bulduğu tarihten başlayarak 5 yıl sonrasında iptal davasına konu olamazlar (AATUHK md. 26).

6183 Sayılı Kanun doğrultusunda alacaklı tarafın iptal davası açma hakkı 5 yıllık süre içinde kullanılması gerekmektedir. Aksi halde zamanaşımı devreye girmekte ve bu hak düşmektedir. Bu sürenin hak düşürücü yapıda olması ile beraber borçlu tarafın, mülkünden geçersiz bir muamele ile çıkarmış olduğu mal henüz karşı tarafın tasarrufuna geçmemiş ise, açılacak olan hakediş davasında, alacaklı tarafın, süreden bağımsız olarak savunmaya giderek iptal iddiasında bulunabileceği genel olarak kabul edilmektedir. Burada üzerinde durulması gereken diğer önemli bir nokta ise, beş yıllık sürenin mi yoksa 27 ve $29^{\prime}$ uncu maddelerde geçen sürenin mi uygulanacağ 1 sorunudur. Ancak belirtmek gerekir ki, 26'ncı maddede ki süre 5 yıl ve daha genel bir yapıda iken 27 ve 29'uncu maddelerde yer alan süre 2 yıl ve daha özel niteliktedir (AATUHK md. 26, 27, 29).

\section{TASARRUFUN İPTALİ DAVASINDA HÜKÜMSÜZ SAYILAN TASARRUFLAR}

6183 sayılı AATUHK' un 24. ve 31. Maddesinde sayılan belli başlı işlemlere girişen kamu borçlusunun gerçekleştirdiği bir takım temlik işlemleriyle borç taahhütlerinin, adli yargıda açılacak davalar ile hükümsüz saydırılması suretiyle kamu alacağının tahsilinin sağlanmasına yönelik düzenlemelere yer verilmiştir. Buna göre, zamanaşımı süresi içinde kalmak şartıyla, kamu borçlusunun yaptığı bağışlar, ivazsız tasarruflar, belli yakınlıktaki kimselere temlik edilip de bağışlama sayılan tasarruflar, kamu alacağının tahsilini imkânsız kılmak için yapılan işlemler hükümsüz sayılarak iptal edilebilecektir (Özvatan, 2014: 98).

\section{TASARRUFUN İPTALİ DAVASININ KOSULLARI}

Kesinleşen bir kamu alacağının mevcut olması durumunda ancak iptal davası açılabilmektedir. Açılacak iptal davası için aynı zamanda asıl borçluya yönelik yapılan takip ve kovuşturmadan sonuç alınamamış olması gerekmektedir. O halde, ilk olarak iptal davalarının, bu unsurları taşıyıp taşımadığının saptanmasıı gerekmektedir. Çünkü bu koşullar, iptal davasının açılma koşullarını içeren önemli hususlardır. Diğer bir deyişle yapılan kovuş̧urma sonucunda borçlunun kayda geçmemiş bir tasarrufu bulunduğunda veya istenen teminat karşıllığını bulduğu taktirde iptal davasına sebep oluşturan hiçbir unsur yoktur (Gerçek,2015: 202).

\section{A. Kamu Alacă̆ının Kesinleşmiş Olması}

Kesinleşen ve ödenebilir bir hale gelen bir kamu alacağının bulunması, iptal davasının ilk koşulunu teşkil etmektedir. Bu koşula ek olarak aynı zamanda alacağın tahsili ile görevlendirilmiş amme idaresinin, artık ödenmesi gereken kamu borcunun tahsili için yapmış olduğu kovuşturmadan eli boş ayrılması veya borçlunun teminat göstermiş olmaması gerekmektedir. Dolayısı ile bir koruma yöntemi olarak uygulanan ihtiyatı haciz kararı ile el konulmuş olan malların akıbetinin de kesin olarak belirlenmemesi nedeni ile iptal davasına da konu 
olamamaktadırlar. O halde idare tarafından açılan iptal davasının, borçlu tarafın vergi mahkemesinde kamu borcunun olup olmadığının kesin bir hükme bağlaması yani davanın sonucunun beklenmesi gerekmektedir (http://www.basarmevzuat.com/dergi/2001-12/a/02.htm\#_ftn12).

\section{B. Alacă̆ın Tahsil Olanağının Kalmaması}

İptal davasının açılabilmesi için, öncelikle tahsil dairesinin tüm kanun yollarını denemiş ve alacağını tahsil edememiş olması gerekmektedir. Yapılan kovuşturma sonucunda borçlunun malvarlığının kamu alacağının tahsili için oran olarak yetersiz olduğu anlaşıldığında ancak borçlunun yapmış olduğu tasarruf işlemleri iptal davasına konu olabilecektir. Alacaklı tahsil dairesinin, tüm kanun yollarını denemesine rağmen alacağını tahsil edememesinin öncelikli nedeni; kamu borçlusunun müşkül durumda olduğunu gösteren haciz tutanağının, sonuçları açısından aciz fişi ile tam anlamı ile örtüşmesinden kaynaklanmaktadır. Böylece; borçlunun müşkül durumu için düzenlenen haciz tutanağ 1 , bu durumda geçici bir aciz belgesi niteliği almakta ve alacaklıya tasarrufun iptali davası açabilme firsatı sunmaktadır. Haciz sırasında borçlunun mallarının borcuna yetmediği ortaya konmuş ise, düzenlenen haciz tutanağı artık geçici aciz belgesi statüsü alacaktır. Dolayısı ile iptal davası açılabilmesi için belirlenen ön koşulun yani aciz fişinin ya da aciz belgesinin düzenlenmiş olması değil, borçlunun gerçekten de müşkül durumda olmasına bağlıdır (Akın,2016: 34).

\section{C. İvazsız Tasarrufun Geriye Doğru İki Yıl İçinde Yapılmış Olması}

İptal davası açılabilmesi için diğer bir önemli husus ise tasarruf işleminin ödeme tarihinden itibaren geriye doğru iki yıl içinde yapılmış olması koşuludur. Diğer taraftan, artık ödenmesi gereken kamu alacaklarının tahsil edilme olanağının kalmaması durumunda, borçlu tarafın girişmiş olduğu tasarruf işlemleri sonucu diğer kimselerin ellerinde bulunan mallara dair tasarrufların iptali davası için; borcun tasarruf ediniş tarihinden önce vuku bulmuş olmasına ve borçlu olan tarafın karşılıksız tasarruflarııın ödeme süresinin başladığı tarihten itibaren geriye doğru iki yıl içinde yapılmış olması şartına bağlıdır (Gerçek, 2015: 2004).

Amme alacaklarının ödeme tarihi ve süreleri yasalarla açıklanmış olup, özellikle açıklanmayan bazı durumlarda ise kamu alacakları kural olarak Maliye Bakanlığı'nın mükellefe bildirdiği tarihten itibaren bir aylık ödeme süresine haizdir. Kanuni olarak kamu alacağının vade günü ise ödeme süresinin son günüdür. Yukarıda belirlenen iki yıl şartından farklı olarak burada ödeme süresinin başlangıcından itibaren, vuku bulan ivazsız muameleler ve tediye niteliğindeki işlemler, borcun ortaya çıkış tarihine bakılmaksızın iptal davasına dahil edilerek hükümsüz sayılmaktadır (http://www.basarmevzuat.com/dergi/2001-12/a/02.htm\#_ftn12).

\section{TASARRUFUN IPTALI DAVASI AÇILABILLECEK DURUMLAR}

İptal davasının açılabileceği durumlar iki ana başlık altında incelenecek olursa birincisi, borçlunun hükümsüz sayılan tasarruflarının bulunması, ikincisi ise kamu alacağının tahsiline imkânsız kılmamak için yapılan tasarrufların bulunması halidir.

\section{A. Borçlunun Hükümsüz Sayılan Tasarruflarının Bulunmast}

6183 Sayılı Kanun, kamu alacaklarını güvence altına alırken, şüpheli durum veya açık olarak kötü niyet içeren durumlarda, borçlunun yapmış olduğu bazı tasarrufları batıl kılmıştır. Bu tasarrufları kendi içerisinde sınıflandırır isek; karşllıksız tasarruflar, bağışlama sayılabilecek tasarruflar ve hükümsüz olarak sayılabilecek diğer tasarruflar olarak sınıflandırabiliriz.

\section{i. İvazsı Tasarruf Kavramı}

Hukuki işlemleri, karşı edim yani bir ivaz karşıllı̆ında olup olmamasına göre ivazlı veya ivazsız tasarruflar olarak sınıflandırmak mümkündür. Buna göre, ivazlı tasarruflarda, taraflardan birinin edimine karşılık, diğer tarafın bir karşı ediminin olması gerekmektedir. İvazsız tasarruf, borçlunun herhangi bir karşılık almadan yaptığı ve sonucunda başkalarının malvarlığında zenginleşmeye neden olan bir hukuki işlemdir.

Borçlunun borcunu ödemeyeceği bilinen bir kişi lehine ipotek tesis etmesi, böyle bir kişiye kefil olması, bir derneğe yardımda bulunması gibi işlemler, ivazsız tasarrufa örnek olarak gösterilebilir. Bağışlama da ivazsız bir tasarruf olmasına rağmen, iptal hükümlerini düzenleyen maddelerde özel olarak ifade edilmiştir. Bağışlama da bir ivazsız tasarruf olmakla ivazsız tasarrufların hükümsüz sayılmasının amacı, kamu alacaklarının borçlarını ödemek istemeyen borçlulara karşı korunmasıdır. 6183 Sayılı Kanun"e un 27. maddesine göre ivazsız tasarrufların hükümsüzlüğüne karar verilebilmesi için bazı şartların gerçekleşmesi gerekmektedir. Öncelikle, madde hükmü uyarınca ivazsız tasarrufların geçersiz sayılması amacıyla iptal davası açılabilmesi için, kamu alacağının 


\section{BŞEÜ Sosyal Bilimler Dergisi}

6 (2), 323-332, 2021
BSEU Journal of Social Sciences

https://doi.org/10.33905/bseusbed.1005270

kesinleştikten sonra istenebilir hale gelmesi ve cebri tahsil ve takip yolları sonunda kamu alacağının tahsil edilemeyeceğinin anlaşılması gerekmektedir (Akın, 2016: 49).

\section{ii. İvazsız Tasarruflar}

6183 Sayılı Kanun gereğince kamu borcunu ödemeyenlerin veya hapsen tazyikine rağmen mal bildiriminde bulunmaktan kaçınanlar ile malı bulunmadığın bildiren ya da idarenin bilgisine sunulan malların borcuna oranla yetersin kaldığı anlaşılanların ödeme müddetinin başlangıcından itibaren geriye doğru iki yıl içerisinde veya ödeme süresinin başlamasından sonra yaptıkları tediye ve karşılıksız tasarruflara konu olan işlemler hükümsüzdür (AATUHK md.27).

İvazsız tasarruflar; herhangi bir karşılık alınmadan yapılan bir hukuki işlemlerdir. Borçlu tarafın herhangi bir kazanımı olmadan alacağından feragat etmesini, miras hissesinden vazgeçmesini veya bir mal vermeyi söz vermesi ivazsız tasarrufa örnek teşkil eder (Gerçek,2015:205).

$\mathrm{Bu}$ örneklerden de anlaşılacağı üzere ivazsız tasarrufların iptali bazı şartlara bağlanmıştır. Bu şartlar;

•Borçlunun kamu alacağının tamamını veya bir kısmını ödememiş olması

-Borçlunun, mal beyanında bulunmamış olması veya beyan edilen malın borcu karşılayacak düzeyde olmadığının anlaşılması

•İvazsız tasarrufun, ödeme süresinin başlangıcından önceki iki yıl içinde yapılmış olması (AATUHK md.27).

Yukarıda sayılan bu şartların hepsi aynı anda vuku bulunmalıdır. Bir şartın yokluğu, ivazsız tasarrufunun hükümsüz olarak nitelendirilmesine engel teşkil etmektedir (http://www.basarmevzuat.com/dergi/200112/a/02.htm). Aynı zamanda borcun ödeme tarihinden başlayarak geriye doğru 2 yıllık süre zarfinda gerçekleşmiş olması tasarruf işleminin hükümsüz kılınmasına sebep teşkil etmektedir.

\section{B. Bă̆ışlama}

Bağışlama; bir kimsenin karşılığında bir ivaz taahhüt etmeksizin malının bir kısmını veya tamamını diğer bir kimseye devretme sözleşmesidir.

\section{i. Bă̆ı̆ı̧lama Sayılan Tasarruflar}

Bağışlama; bir kimsenin karşılığında bir ivaz taahhüt etmeksizin malının bir kısmını veya tamamını diğer bir kimseye devretme sözleşmesi şeklinde yapılabileceği gibi kötü niyet taşıyarak Mal kaçırmanın kolay yolu olan bağışlamaya yönelik kanun koyucu AATUHK'un 28.maddesi doğrultusunda bazı tasarrufları bağışlama sayarak iptal davasına dahil etmiştir (Gerçek,2015:205). Buna göre;

•Borçlunun üçüncü derece de dahil olmak üzere kan hısımlarıyla, eşler ve ikinci derece de dahil olmak üzere kanun yolu ile kurulan hısımlar arasında yapılan ivazlı tasarruflar,

•Kendi verdiği malın, akdin yapıldığı sıradaki değerine göre borçlunun ivaz olarak pek aşağı bir fiyat kabul ettiği akitler,

•Borçlunun kendisine ya da üçüncü bir kimsenin yararına ölünceye dek gelir ve yararlanma hakkı sunduğu sözleşmeler bağışlama sayılan tasarruflar arasında yer alır (Çomaklı, Ak ve Ayrangöl, 2013: 180).

\section{Hükü̈msüz Sayılan Diğer Tasarruflar}

Kamu alacağının kötü niyete açık olan borçluya karşı korumak amacı ile getirilen önlemler yapısı itibari ile amme borçlusunun mal kaçırmasını önlemek sebebi ile düzenlenmiştir. 29. maddeye uyarınca, üçüncü kişilerin iyi niyetli olmalarına bakılmadan, yani borçlu tarafın suiniyetinden habersiz olsalar bile, iptal davasına konu olan tasarruflar iptale tabidir (Özhan, 2010: 105-106).

İptal davasına haiz diğer hükümsüz tasarruflar şunlardır:

•Borçlunun teminat göstermeyi önceden kabul ettiği durumlar dışında, borçlunun mevcut bir borcun temini için yapmış olduğu rehinler,

-Borcuna karşı1ık gelen para ya da mutat ödeme araçlarından farklı şekilde yapılan olan ödemeler,

-Muaccel olmayan yani müeccel bir borç için yapılacak olan ödemeler (AATUHK md. 29). 


\begin{tabular}{|c|c|c|}
\hline & $\begin{array}{l}\text { BŞEÜ Sosyal Bilimler Dergisi } \\
6(2), 323-332,2021\end{array}$ & $\begin{array}{r}\text { BSEU Journal of Social Sciences } \\
\text { https://doi.org/10.33905/bseusbed.1005270 }\end{array}$ \\
\hline 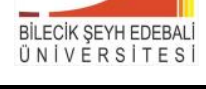 & $e-I S S I$ & V:2548-088X (https://dergipark.org.tr/tr/pub/bseusbed) \\
\hline
\end{tabular}

Genel çerçevede ele alındığında; ödeme zorluğu çeken borçlunun yapmış olduğu bu işlemlerin hileli ödemeler olduğunun farkına varılmaktadır. Dolayısıyla burada kamu borçlusu elindeki varlığının kaydırılması suretiyle kamu alacağının tahsilinden kurtulmaya çalışılması söz konusudur. Bu tür durumların önüne geçmek amacıyla kanun koyucu, görüldüğü üzere çeşitli düzenleme yollarına başvurmaktadır (Bozdanaoğlu,2013: 116).

\section{Kamu Alacă̆ı̆ın Tahsiline İmkân Bırakmamak Amacıyla Yapılan Tasarrufların Bulunması}

6183 Sayılı AATUHK'un 30. Maddesi uyarınca; borçlunun malının olamaması veya borcunu ifa edecek düzeyde olmadığının anlaşılması, kamu alacağının tamamının veya bir kısmının tahsilini imkânsız bırakmak amacı ile borçlunun yapmış olduğu tek taraflı işlemler ile borçlunun kastıı bilen veya bilebilecek durumdaki kimseler ile yapılan bütün muamelelerin tarihleri ne olursa olsun geçersizdir. Belirtilen tek taraflı işlemden maksat, karşı tarafın iradesini açıklamasına ihtiyaç duyulmadan sadece amme borçlusuna yönelik yapılan hukuki işlemleri barındırır (Kılıç,2011: 65). Bu hüküm ile borçlunun açık olarak kötü niyete yer verdiği tasarruf işlemlerinin önüne geçilmesi hedeflenmiştir.

\section{ACIZZ HALINDE İKEN YAPILAN TASARRUFLAR}

6183 Sayılı Kanun'un 29.maddesinde, kötü niyet taşıyan borçluya karşı amme alacağını korumaya yönelik getirilen diğer önlemler, hükümsüz sayılan diğer tasarruflar adı altında belirtilmektedir. Kanunda geçen bu önlemler, kamu borçlusu sıfatında bulunan kişinin, kamu alacağına sahip olan kamu idaresinden haczi kabil malvarlığını kaçırmasını önlemeye yönelik getirilen tedbirlerdir. Anılan kanunun 29. madde metninde; "Amme alacağını ödemeyen borçlulardan müddetinde veya hapsen tazyikine rağmen mal beyanında bulunmayanlarla, malı bulunmadığını bildiren veyahut beyan ettiği malların borcuna kifayetsizliği anlaşılanların ödeme müddetinin başladığı tarihten geriye doğru iki yıl içinde veya ödeme müddetinin başlamasından sonra yaptıkları tasarruflardan aşağıda belirtilenler hükümsüzdür:

-Borçlunun teminat göstermeyi evvelce taahhüt etmiş olduğu haller müstesna olmak üzere borçlu tarafından mevcut bir borcu temin için yapılan rehinler,

-Borca karşı1ık para veya mutat ödeme vasıtalarından gayrı bir suretle yapılan ödemeler,

•Vadesi gelmemiş bir borç için yapılan ödemeler. "Tasarrufun iptali nedeni olarak sayılmıştır (Akın, 2016: 54-55).

\section{TASARRUFUN IPTALİ DAVASINDA GÖREVLİ VE YETKILİ MAHKEME}

6183 sayılı AATUHK'nun 24. maddesine göre; alacaklı kamu idaresinin, kamu borçlusunun kanunda belirtilen sebepler ile hükümsüz sayılan tasarruf ve işlemlerinin iptali için asliye hukuk mahkemesinde dava açması ve bu davanın başka işlere kıyasla ivedilikle görülmesi gerekmektedir. Kanunda tasarrufun iptali davaları yönünden herhangi bir yetki kuralı bulunmamaktadır. Bu sebeble kanunda geçen sebeplerle yapılan tasarrufların hükümsüzlüğüne karar verilmesini sağlamak için açılacak olan tasarrufun iptali davalarında yetkili mahkemenin, 6100 sayılı Hukuk Muhakemesi Kanununa göre belirlenmesi gerekmektedir. Bu kanundan anlaşılması gereken ise her dava kanunda aksine hüküm bulunmadıkça, açıldığı tarihte davalının ikametgâhı sayılan yer mahkemesinde görülmesi gerekir. Aynî nitelikte bir dava olmayan tasarrufun iptali davası sonucunda iptali istenmiş olan tasarruf bir taşınmaza ilişkin olsa bile, davanın davalının ikametgâhının bulunduğu yerde açılması; tasarrufun iptali davasında, taşınmaz malın bulunduğu yer mahkemesinde açılacağına dair kesin bir yetkiye dayanan kuralının uygulanmadığı anlaşılmaktadır (Ağar, 2015: 161).

\section{TASARRUFUN IPTALI DAVASININ 6183 SAYILI AATUHK İLE IIIK'NUNDA YER ALMASINDAKI FARKLILIK SEBEBİ}

Günümüzde mevcut kamu alacaklarının takip ve tahsiline dair hükümler, 6183 Sayılı Amme Alacaklarının Tahsil Usulü Hakkında Kanun ile düzenlenmiştir. Mevcut kanun, özel hukuk borç ilişkilerinden ortaya çıkan alacakların takip ve tahsil işlemlerine dair hükümleri kapsayan 2004 Sayılı İcra ve İflas Kanunu'ndan ayrı hükümler içermektedir. Sebebi, alacaklı konumunda olan devletin, kamu hizmetlerinin finansmanında başvurulacak vergi ve diğer gelirlerden meydana gelen kamu alacaklarının hızlı ve etkin tahsil edilmesinin arzu edilmesidir. Kanun koyucu, bu sebep ile kamu alacaklarının takip ve tahsiline dair özel hükümler oluşturarak kamu alacaklısı niteliğine sahip olan tahsil dairesine önemli imkanlar tanımıştır.

6183 Sayılı Amme Alacaklarının Tahsil Usulü Hakkında Kanun' un, 2004 Sayılı İcra ve İflas Kanunu'na göre ön plana çıkan önemli niteliklerinden biri kamu alacaklarının nasıl korunacağını ifade eden hükümleridir. Bu 


\begin{tabular}{|c|c|c|}
\hline & $\begin{array}{l}\text { BȘEÜ Sosyal Bilimler Dergisi } \\
6(2), 323-332,2021\end{array}$ & $\begin{array}{r}\text { BSEU Journal of Social Sciences } \\
\text { https://doi.org/10.33905/bseusbed.1005270 }\end{array}$ \\
\hline$u$ & $e-I S S I$ & v:2548-088X (https://dergipark.org.tr/tr/pub/bseusbed) \\
\hline
\end{tabular}

önemli hükümler ile tahakkuk ederek borçlusu için cebri icra yoluna yönelen ya da tahakkuk etmediğinden dolayı istenebilir niteliğe kavuşmamış olan kamu alacakları tahsilinin tehlike yaratması halinde alacakların güvence altına alınması hedeflenmiștir. Kamu alacaklarının korunması için başvurulan yöntemlerden biri de tasarrufun iptali davalarıdır. 6183 Sayılı Kanun' un 24 ile 31. maddelerinde düzenlenen iptal davaları, 2004 Sayılı İcra ve İflas Kanunun' un 277 ve devamı maddelerinde düzenlenen tasarrufun iptali davalarına dair hükümler dayanak alınarak kamu alacakları kısmı düzenlenmiştir (Akın, 2016: 90).

\section{YILLAR ITTIBARIYLE TASARRUFUN İPTALI DAVASI}

Tasarrufun iptali davalarını geçmişten günümüze incelediğimizde devamlı artış eğilimi gözlenmektedir. Tablo 1'de görüldüğü gibi 2005 yılı ve sonrasında artışlar dikkat çekmektedir. Bu dikkati çeken artış miktarı vatandaşların ticari hayatlarında dürüstlükten uzaklaştıklarını göstermektedir.

Tablo 1.Yıllar İtibariyle Tasarrufun İptali Davası

\begin{tabular}{|l|l|l|l|l|l|l|l|}
\hline Yıl & \multicolumn{1}{|c|}{$\begin{array}{c}\text { Dava } \\
\text { Sayısı }\end{array}$} & $\begin{array}{c}\text { Davacı } \\
\text { Sayısı }\end{array}$ & $\begin{array}{c}\text { Davalı } \\
\text { Sayısı }\end{array}$ & \multicolumn{1}{|c|}{ Yıl } & $\begin{array}{c}\text { Dava } \\
\text { Sayısı }\end{array}$ & $\begin{array}{c}\text { Davacı } \\
\text { Sayıs }\end{array}$ & $\begin{array}{c}\text { Davalı } \\
\text { Sayısı }\end{array}$ \\
\hline $\mathbf{1 9 9 8}$ & 302 & 329 & 491 & $\mathbf{2 0 1 0}$ & 2.653 & 3.107 & 7.424 \\
\hline $\mathbf{1 9 9 9}$ & 424 & 454 & 767 & $\mathbf{2 0 1 1}$ & 2.876 & 3.197 & 8.181 \\
\hline $\mathbf{2 0 0 0}$ & 264 & 315 & 425 & $\mathbf{2 0 1 2}$ & 3.251 & 3.788 & 10.018 \\
\hline $\mathbf{2 0 0 1}$ & 465 & 507 & 888 & $\mathbf{2 0 1 3}$ & 3.775 & 4.316 & 11.668 \\
\hline $\mathbf{2 0 0 2}$ & 551 & 692 & 1.055 & $\mathbf{2 0 1 4}$ & 3.792 & 4.514 & 12.102 \\
\hline $\mathbf{2 0 0 3}$ & 1.004 & 1.161 & 1.698 & $\mathbf{2 0 1 5}$ & 4.604 & 5.251 & 13.531 \\
\hline $\mathbf{2 0 0 4}$ & 785 & 955 & 1.450 & $\mathbf{2 0 1 6}$ & 5.780 & 6.452 & 16.313 \\
\hline $\mathbf{2 0 0 5}$ & 1.037 & 1.297 & 2.260 & $\mathbf{2 0 1 7}$ & 6.570 & 7.424 & 18.131 \\
\hline $\mathbf{2 0 0 6}$ & 1.276 & 1.626 & 3.012 & $\mathbf{2 0 1 8}$ & 7.350 & 8.225 & 19.721 \\
\hline $\mathbf{2 0 0 7}$ & 1.477 & 1.958 & 3.673 & $\mathbf{2 0 1 9}$ & 8.228 & 9.329 & 22.894 \\
\hline $\mathbf{2 0 0 8}$ & 2.366 & 2.867 & 5.933 & $\mathbf{2 0 2 0}$ & 10.682 & 11.749 & 30.003 \\
\hline $\mathbf{2 0 0 9}$ & 2.703 & 3.092 & 7.634 & & & & \\
\hline
\end{tabular}

Kaynak: https://adlisicil.adalet.gov.tr/

Tasarrufun iptali davası, icra takibine konu ve teminatsız kalan alacağın tahsiline bağlı olmasına rağmen açılan icra takip oranlarından daha yüksek oranda olduğu görülmektedir. Gözlemlenen bu yükssek artışın mevcut borçlu sayısını da artıracağı ve daha fazla kişinin de borç sorumluluğu altına gireceğinin göstermektedir. Davaların değerlendirilmesinde tescile dayalı varlıklar ile hakların mülkiyet devirleri nezdinde tasarrufun iptali davalarının daha fazla açıldığı ortaya çıkmaktadır (Korkmazarslan, 2018: 41-42).

\section{TASARRUFUN İPTALİ DAVASININ SONUÇLARI}

AATUHK'nun 31 Sayıılı Maddesi, alacaklı kamu idaresinin açmış olduğu iptal davasının kabul edilmesi halinde ne gibi faydalar sağlayacağını içermektedir. Buna göre alacaklı kamu idaresi iptal davasını kazandığında, davaya konu olan malın kimin elinde olduğuna bakmaksızın haczettirme yetkisine kavuşur. Elde ettiği bu yetki ile davaya konu olan malı haczeder, satar ve satış sonucunda elde ettiği gelirden de alacağının tahsilini gerçekleştirmektedir (Gerçek,2015: 208).

Alacaklı kamu idaresi tarafından kazanılan iptal davası ile bu tasarruf işleminden yararlananlar elde ettikleri kazanımları, elden çıkarmışlarsa belirlenecek bedelini ödemek zorundadırlar. Karşlık olarak verilen şeyler dolayısı ile alacaklı taraf olan kamu idaresinden bir istekte bulunamazlar ve sonuçlarına katlanmak zorundadırlar (AATUHK md. 31).

Alacağın tahsiline yetecek kadar tasarrufun iptaline karar vermek aslında iptal davasının amacını oluşturmaktadır. Diğer yönden incelendiğinde, motorlu taşıtların trafiğe kayıt ve tescili veya taşınmazın tapu kaydı idari bir işlem niteliğindedir; bu nedenle karar organından bu konuda bir hüküm vermesi istenemez. Aksi bir kararda, tapunun iptali ve borçlu adına yeniden tescili hali ortaya çıkmakta ve bu durumda borç miktarı alacak miktarını aşabilmektedir. Dolayısıyla, bu işlemlerin iptaline veya borçlu adına düzeltilmesi yanlış kabul edilmektedir. Burada yapılması gereken, kamu alacağının tahsiline yetecek miktardaki tasarrufun iptaline karar verilmesidir. Yargıtay kararlarına bakıldığında da aynı düşünce hakimdir. 
Kamuya borçlu bulunan kişilerden mal edinenimi sağlayanlar kamuya tahsil edilmeyen borçları ödemesi sonucu açılmış bulunan iptal davalarının son bulmasını talep edebilir. Borçlar ödendiği taktir de açılmış olan iptal davası son bulmaktadır. Aksi bir durum olması sonucunda ise malı satın alanın iyiniyetli olup olmamasına önemsiz olacak ve iptal davası sonucunda malın mülkiyeti malı edinende kalmakla birlikte alacaklı kamu idaresi haciz ve satış işlemini müteakip kamu alacağını tahsil eder. Satışın gerçekleşmesi sonucunda kamu alacağına karşıladıktan sonra artan fazla bir para olması durumunda, bu para kamu borçlusundan malı elde edene verilmektedir. Kamu borçlusunun kamu alacağının tahsilini engellemeye ya da zorlaştırmaya yönelik tasarruf ve işlemlerde bulunması halinde, alacaklı konumunda bulunan kamu idaresine, bu tasarruf ve işlemlerin iptali için dava açma hakkı tanınmaktadır. 6183 sayılı AATUHK 'nun 24-31. maddelerinde düzenlenen tasarrufun iptali davasına ilişkin hükümler İIK'nun 277-284. maddelerinde düzenlenen iptal davasına ilişkin olan hükümlerle benzerlik göstermektedir. Kamu borçlusu bulunan kişi ile hukukî bir muameleye gerçekleştirmiş kişilerin iyi niyetli olup olmamaları durumları da İIK'dan farklı olarak kamu alacaklısı lehine olacak şekilde bazı hükümler bulunmaktadır. Hükümsüz olarak sayılacak olan tasarrufların iptalinde alacaklı kamu idaresinin davacı; üçüncü kişilerin ise, davalı olduğuna dikkat edilmesi gerekmektedir. Kamu borçlusu durumunda bulunan kişilerin yaptığı tasarrufların kamu alacaklısı bakımından hükümsüz sayılmasına ilişkin açılan tasarrufun iptali davası, amme alacaklısına yönelik olmakla beraber, amme borçlusu ve üçüncü kişiler hakkında farklı sonuçlar doğurmaktadır (Ağar, 2015: 162,163).

\section{SONUÇ}

Ülkemizde devletin sahip olduğu kamu alacaklarının takibinde ve tahsilinin de uygulanacak olan hükümler, 6183 Sayılı AATUHK'un da yer almaktadır. Bahsedilen kanunda özel hukuka ilişkin borç ilişkilerinden kaynaklanan alacakların takibinde veya tahsilinde uygulanacak olan hükümleri içeren 2004 Sayılı İIK'ndan farklı olarak uygulanacak olan hükümler yer almaktadır. Bunun sebebi ise alacaklı konumunda olan devletin, sunacağı kamu hizmetlerinin finansmanında başvurulacak vergi ve diğer gelirlerden meydana gelen alacakların verimli etkin ve tutumlu bir şekilde hızlı ve etkili olarak tahsilini istemesinden kaynaklanmaktadır. Burada kanun koyucun amacı kamu alacaklarının gerek takip gerekse tahsiline dair özel birtakım hükümler ile kamu alacaklısı durumunda bulunan tahsil dairesine birtakım önemli avantajların yanında kamu alacaklarının korunmasında da kamu idaresine yardımcı olmaktır. 6183 Sayılı AATUHK' un, 2004 Sayılı İK'ndan en önemli farklılıklarından birisi kamu alacaklarının korunması metotlarının belirtildiği hükümlerin yer almasıdır. Mevcut hükümler vasıtasıyla tahakkuk yoluyla borçlu hakkında cebri icra yoluna başvurulan ya da tahakkuk olmadığından istenebilir niteliğe kavuşmamış kamu alacaklarının tahsilatının tehlikeli bir duruma düşebilecek olması hallerinde kamu alacaklarının tahsilatının bir ön tedbir olarak önceden güvence altına alınmasının amaçlandığı ortadadır.

Kamu alacaklarını korumaya yönelik metotlarından bir diğeri de tasarrufun iptali davasının açılma durumudur. Bu dava, şahsi nitelikli bir eda davasıdır. Tasarrufun iptali davasında amaç ise; Kamu alacağına sahip devletin borçlarını ödemeyen ya da borca yetecek kadar malvarlığı olmayan borçlunun, borçlarını ödememesi ve arka planında alacaklısına zarar verme kastı taşımasıdır. Bu yolla malvarlığından gerçekleştirdiği tasarrufların, açılacak bir dava ile kamu alacaklısı yönünden geçersizliğinin tespit edilerek ve dava konusu değerlerin cebri icra yolu satılması ile bu kamu alacaklarına sahip olan devletin alacağının güvence altına alınması sağlanabilmektedir.

6183 sayılı AATUHK' un 24 ile 31. maddelerinde hüküm altında bulunan iptal davaları borçluların alacaklarını zor duruma sokan ve zarar veren bir dava şekli olarak tanımlanmıştır. İptal davası şekil olarak diğer koruma yöntemlerinde de olduğu gibi; borçluların alacaklılardan mal kaçırmasını engellemek ve kötü niyetli olarak yapmış oldukları hukuki muamelelerin geçersiz kılınarak, alacağın tahsilini sağlamaktır. Görülüyor ki tasarrufun iptali davalarının asıl hedefi borçlunun mal kaçırmak olan girişimlere engel olmaya çalışmaktadır.

Ödeme zorluğu çeken borçlunun yapmış olduğu bu işlemler borçlunun zor zamanında yaptığı işlemlerdir. Burada kamu borçlusu elindeki varlıklarını başkasına aktarımı yolu ile üzerine düşen borçtan kurtulmaya çalışmaktadır. Ancak devlet açısından önem arz eden kamu gelirleri, çeşitli müesseseler ile korunmaktadır. İste burada amme alacaklarının korunması yöntemleri devreye girmektedir.

İptal davasının açılabilmesi için kamu alacağının gerçekleşmesi, kesinleşmesi ve ödenebilir aşamaya gelmesi gerekmektedir. Tasarrufların hükümsüz kılınmasına ilişkin iptal davası için aynı zamanda bir şahsi dava niteliğindedir. Assl borçlunun takibinin sonucunda olumlu geri dönüşler alamayan ve artık borcun ödenemez hale geldiğinin kanaatine varırsa alacaklı kamu idaresi bu aşamadan sonra borçluya karşı iptal davası açabilmektedir. $\mathrm{O}$ halde, tasarrufa ilişkin iptal davalarının ilk koşulu, bu unsurları taşıyıp taşımadığının saptanması gereğidir. Çünkü bu koşullar, iptal davasının açılma koşullarını içeren önemli hususlardır. Diğer bir deyişle yapılan takip sonucunda borçlunun kayıt altına alınmamış bir borcu ortaya çıkabilir ve bu durumda alacaklı idare kayıt altına alınmayan maldan ilk önce tahsil etmeye çalışacaktır. Eğer malı yok ya da ödemeye yetmiyor ise teminat 
vermekten de kaçınıyor ise iptal davasının konusuna giren işlemlerde bulunmuş olmaktadır. 6183 Sayılı AATUHK' da bu durumda kendisine uygulama alanı bulacaktır.

Kamu alacağının tehlikeli bir duruma düşmesi durumunda tahsil edilme aşamasına gelmiş ya da tahsili gecikmiş alacaklarda kamu alacakları bakımından değerlendirildiğinde tahsil etme olanağının olmaması halinde cebri icra yoluyla tahsil etmeye çalışmak yerine kamu alacaklarını muhafaza edici yöntemlerin geliştirilmesi ve uygulanması bu kamu alacağını daha kısa bir surede ve tam olarak tahsil edilebilmesi durumları gibi avantaj sağlamakta ve kamu alacağı da güvence altına alınmış olmaktadır. Kamu borçlusu bakımından düşünülürse de kamu alacaklısının tahsili gerçekleştirilecek olan alacaklarını koruyucu önlemlerin alındığının bilmesi kamu borçlusu tarafinda kamu borcunun ödemek zorunda olduğu borcunu zamanında ve eksiksiz olarak ödenmesini sağlayıcı bir rol oynamaktadır. Kamu alacaklısının kamu alacaklarını muhafaza altına alabilmek ve de tahsilini gerçekleştirebilmek için kamu alacaklısının sahip olduğu alacağın doğumundan tahsil aşamasına kadar tüm aşamalarda kamu alacaklarını koruyucu önlemlerin uygulanması ve bu hükümlerle donatılması gerektiği aşikardır.

Sonuç olarak ülkemizde kamu alacaklarının takip ve tahsili yürürlüğe girdiği 01.01.1954 tarihinden beri AATUHK' ya göre yürütülmektedir. AATUHK yaklaşık altmış beş yıldır yürürlükte olmasına rağmen en az değişikliğe uğrayan kanunlardan biridir. Teknolojik ve ekonomik alanda meydana gelen gelişmeler sonucunda AATUHK' nın kamu alacaklarını koruma noktasında yetersiz kaldığı ve eksiklikleri görülmektedir. Yani yürürlükte olan 6183 Sayılı AATUHK 'nın günümüz ihtiyaçlarını tam anlamıyla karşılayamadığını görmekteyiz. Bunun için birtakım öneriler sunmak gerekirse bu belirtilen önerilerin etkin ve verimli bir şekilde uygulanması sonucunda olumlu sonuçlar alınabilecektir.

6183 Sayılı AATUHK da kamu alacaklısı ve kamu borçlusu durumunda olanların hak ve menfaatlerinin korunmasına dikkat edilmelidir. Alacakların korunma altına alınmasında, alacaklı olan tahsil dairesi ile kamu borçlusu ilişkisinde karşılıklı olarak hak ve menfaatlerin korunması noktasında henüz bir denge kurulamamıştır. Kamu alacaklısı ve kamu borçlusunun hak ve menfaatleri ön plana çıkarılsa da kamu borçlusunun aleyhine düzenlemeler halen yetersizdir. İhtiyaç duyulan düzenlemeler ile kamunun alacaklarının korunmasında belirli bir yol olmalı ve düzenlemeyi bozan uygulamalar engellenmeye çalışılmalıdır.

6183 Sayılı AATUHK günün şartları dikkate alınarak revize edilmelidir. Başvurulan bu kanun 1954 yılından beri kullanılmakta fakat günümüz koşulları itibariyle kamu alacaklarının korunması noktasında yetersiz kalmaktadır. Tabi ki bu durum mevcut kanunun alacaklı tahsil dairesi ile kamu borçlusunun ihtiyaçlarına tamamen yetersiz kaldığı anlamını da taşımamaktadır. Gerçekleştirilecek yasal düzenlemeler yoluyla 6183 sayılı kanunun günümüz mevcut koşullarına cevap verecek şekilde revize edilmesine ihtiyaç duyulmaktadır. Böylece yasal düzenlemeler vasıtasıyla kamu alacaklarının daha etkin bir şekilde gerçekleştirilmesi mümkün olacaktır.

Kamu alacaklarını güvence altına alan yollar net bir sınıflandırmaya tabi tutulamamaktadır. Tahakkuk etmiş hem de tahakkuk etmemiş kamu alacaklarını güvence altına almak için çeşitli yollar bulunmaktadır. Bu yollar geliştirilerek ön plana çıkarılmalıdır. Ülkemizde belirli dönemlerde gündeme gelen vergi affı uygulamaları, vergi kanunlarına aykırı davranan mükelleflerin cezalarının ve hukuki yaptırımlarının yine idare tarafından büyük bir kısmının affedilmesi olarak tanımlanabilir. Türkiye tarihinde 1980’ den günümüze gelindiğinde neredeyse üç yılda bir yeni vergi afları çıkarılmıştır. Mevcut 6183 Sayılı Kanun çerçevesinde vergi ve resim konularında ve cezalarında af uygulamalarından mümkün olduğunca kaçınılmalıdır. Mali yükümlülüklerini zamanında gerçekleştiren mükellefler bu yollarla cezalandırılmamalıdır. Bir yandan kamu alacaklarını tahsil etme hakkı tanırken bir yandan da kanunun vergi mükelleflerindeki etkisini olumsuz etkilemektedir.

6183 Sayılı AATUHK da yer alan kamu alacağın tahsili gerçekleştirilirken satış konusu olan varlığın değerinin tespitinde dikkatli davranmalıdır. Taşınmazların mevcut satış bedellerinden satılması önem arz etmektedir. Aynı zamanda belediye rayiç bedellerinden satışına imkân verilmemesi, bölgesel düzeyde piyasa rayiç bedelleri belirlenerek bu miktarların altında satış tutarlarının vergilenmesine müsade edilmemesi gerek kamu gerekse özel kişileri koruma amaçlı olacaktır. Satış işlemlerinin konunun uzmanı kişiler tarafından avukatlar, hukuk büroları, gayrimenkul alım-satımı konusunda uzman kişiler vasıtasıyla ve önderliğinde yapılması, alıcının satış esnasında satıcının borçluluk vaziyeti sebebiyle ileriye yönelik beş yıl süresinde karşılaşabilecekleri davalar ile ilgili bilgilendirilmesi olası dava zararlarına engel olacaktır.

Belirtilen bu öneriler dikkate alınıp tahsilat aşamaları tartışmalı konuları sonuca bağlayan, daha sade ve günümüz tahsilat yöntemlerine daha uygun bir kanunun düzenlenmesi yararlı olacaktır. 
BŞEÜ Sosyal Bilimler Dergisi

6 (2), 323-332, 2021
BSEU Journal of Social Sciences

https://doi.org/10.33905/bseusbed.1005270

\section{KAYNAKLAR}

Akın, B. (2016). Amme Alacaklarının Korunması Yöntemlerinden Tasarrufun Íptali Davası, (Yayımlanmamış Yüksek Lisans Tezi), Çağ Üniversitesi Sosyal Bilimler Enstitüsü, Adana.

Ăgar, S. (2015). Özel Hukuk İşlemlerinin (Tasarruflarının) İptaline İlişkin Davaların Vergi Hukukuna Yansımaları, Vergi Sorunları Dergisi, ay,11 S: 326, 161-163.

Bozdoğanoğlu, B. (2013). 6183 Sayılı Kanun Gereğince İptal Davasına Konu Tasarruf ve İşlemlerin Tüzel Kişiler Açısından Uygulanması. Calisma Dünyasi Dergisi, 1 (2), 111-120.

Çomaklı, Ş., Ak, A., \& Ayrangöl, Z. (2013). Vergi Hukuku, 1.Baskı, Savaş Yayınevi: Ankara.

Gerçek, A. (2015). Kamu Alacaklarının Takip ve Tahsil Hukuku, 4. Baskı, Ekin Yayınevi: Bursa.

Korkmazarslan, M. E. (2018). Tasarrufun İptali Davaları ve Bu Davalar ile Davalara İlişkin Taşınmazların Hukuki, Ekonomik ve Sosyal Yaşama Etkileri ile İyi Niyetli Şahısların Korunması, (Yayımlanmamış Dönem Projesi), Ankara Üniversitesi Fen Bilimleri Enstitüsü.

Kılı̧, L. (2011). Amme Alacaklarının Tahsilinde Teminat, (Yayımlanmamış Yüksek Lisans Tezi), İstanbul Üniversitesi Sosyal Bilimler Enstitüsü, İstanbul.

Öncel, K., \& Çağan, N. (1985). Vergi Hukuku -Genel Klsım, C.1, 2. Baskı, Ankara Üniversitesi Sosyal Bilimler Fakültesi Yayınları, Ankara.

Özhan, T. (2010). 6183 Sayll Yasa Kapsamında Amme Alacaklarının Güvence Altına Alınmasl, (Yayımlanmamış Yüksek Lisans Tezi), Marmara Üniversitesi Sosyal Bilimler Enstitüsü, İstanbul.

Özvatan, S. A. (2014). Vergi İcra Hukuku'nda Kamu Alacaklarının Takip ve Tahsilinde Haciz Uygulamasının Değerlendirilmesi, (Yayımlanmamış Yüksek Lisans Tezi), Celal Bayar Üniversitesi Sosyal Bilimler Enstitüsü, Manisa.

Savaş, H.H. (2001). Kamu Alacaklarında İptal Davası, Mevzuat Dergisi S:48 [Erişim Tarihi: 10.10.2020, https://www.mevzuatdergisi.com/2001/12a/01.htm]

T.B.M.M. (1953). Amme Alacaklarının Tahsil Usulü Hakkında Kanun (1953), T.C. Resmî Gazete, 8469, 28 Temmuz.

T.B.M.M. (2011). Hukuk Muhakemeleri Kanunu (2011). T.C. Resmî Gazete, 27836, 12 Ocak.

T.C. Adalet Bakanlı̆̆ı (2021). Adli Sicil ve İstatistik Genel Müdürlüğ̈̈ [Erişim Tarihi: 12.05.2018, http://www.adlisicil.adalet.gov.tr/adaletistya.html] 